\title{
REPRODUCTIVE RELATIONSHIPS AND DEGREE OF SYNAPSIS IN THE POLYTENE CHROMOSOMES OF THE Drosophila buzzatii SPECIES CLUSTER
}

\author{
MACHADO, L. P. B. ${ }^{1}$, MADI-RAVAZZI, L. ${ }^{2}$ and TADEI, W. J. ${ }^{2}$ \\ ${ }^{1}$ Departamento de Ciências Biológicas, Universidade Estadual do Centro-Oeste do Paraná - UNICENTRO, \\ R. Simeão Camargo Varela de Sá, 3, CEP 85040-080, Guarapuava, PR, Brazil \\ ${ }^{2}$ Departamento de Biologia, Instituto de Biociências, Letras e Ciências Exatas - IBILCE, UNESP, \\ R. Cristovão Colombo, 2265, CEP 15054-000, São José do Rio Preto, SP, Brazil \\ Correspondence to: Luciana Paes de Barros Machado, Departamento de Ciências Biológicas, \\ Universidade Estadual do Centro-Oeste do Paraná, UNICENTRO, \\ R. Simeão Camargo Varela de Sá, 3, CEP 85040-080, Guarapuava, PR, Brazil, e-mail: lpbmachado@ unicentro.br \\ Received April 6, 2004 - Accepted July 12, 2004 - Distributed February 28, 2006
}

(With 7 figures)

\begin{abstract}
The process of speciation occurs through the evolution of any of several forms of reproductive isolation between taxa, including inviability of hybrids. In this work, strains derived from allopatric populations of Drosophila buzzatii cluster species were experimentally crossed in order to evaluate their reproductive and cytogenetic relationships, and to contribute toward understanding the reproductive isolation in this group of sibling species. Although intrastrain crosses were highly fertile, we consider it relevant to discuss the differences in intra- and interspecific fertility and fecundity here. Among 30 interspecific crosses, about $63 \%$ were partially or completely sterile. Fifty three percent of interspecific F1 crosses (female and male F1 crossed) were also partially or completely sterile, in contrast to only one out of 24 intraspecific F1 crosses that was partially sterile. An analysis of hybrid polytene chromosomes revealed complete synapsis, except in the microchromosomes (VI) and in the proximal region of the $\mathrm{X}$ chromosome. The intraspecific divergence observed in this study and the variable degree of chromosome pairing shown here reveal part of the complexity of the speciation process pertinent to Drosophila buzzatii cluster, which is consistent with different traits studied in this cluster.
\end{abstract}

Keywords: Drosophila buzzatii cluster, reproductive isolation, polytene chromosome synapse.

\section{RESUMO}

\section{Relações reprodutivas e grau de sinapse nos cromossomos politênicos de espécies de Drosophila do cluster buzzatii}

$\mathrm{O}$ processo de especiação ocorre pela evolução de qualquer uma das diversas formas de isolamento reprodutivo entre táxons, incluindo inviabilidade de híbridos. Neste trabalho, linhagens provenientes de populações alopátricas de espécies de Drosophila do cluster buzzatii foram cruzadas experimentalmente com o objetivo de avaliar suas relações reprodutivas e citogenéticas, e contribuir para o entendimento do isolamento reprodutivo neste grupo de espécies intimamente relacionadas. Os cruzamentos dentro de uma mesma linhagem foram altamente férteis, contudo as diferenças na fertilidade e fecundidade encontradas intra e interespecificamente são discutidas neste artigo. Dos 30 cruzamentos interespecíficos, $63 \%$ foram parcialmente ou completamente estéreis. Cinqüenta e três por cento dos cruzamentos de F1 interespecíficos (fêmeas e machos F1 cruzados entre si) também foram parcialmente ou completamente estéreis, em contraste com apenas um, em 24 cruzamentos de F1 intra-específicos, que foi parcialmente estéril. A análise dos cromossomos politênicos nos híbridos revelou sinapse completa, exceto nos microcromossomos (VI) e na região proximal do cromossomo X. A divergência intra-específica e o grau variável de pareamento 
cromossômico, observados neste estudo, revelam parte da complexidade do processo de especiação pertinente ao cluster buzzatii, o que é consistente com diferentes caracteres estudados neste cluster.

Palavras-chave: cluster Drosophila buzzatii, isolamento reprodutivo, sinapse nos cromossomos politênicos.

\section{INTRODUCTION}

The study of reproductive isolation patterns regarding species divergence is critical for understanding the speciation process. Such comparative analyses have been conducted in several animal groups (see Lijtmaer et al., 2003 for an example on birds group). Similarities among some studies suggest that the patterns of the evolution of postzygotic isolation, and the process of speciation in general, are shared among animal groups. The genus Drosophila of Diptera has already been studied in terms of reproductive relationships among allopatric and sympatric populations (for example, see Prakash, 1972 and Dobzhansky, 1975). Several studies have demonstrated that interspecific hybrids of Drosophila showed incomplete chromosomal synapsis in comparison with chromosomal synapsis inside the species (Cordeiro, 1968; Evgen'ev, 1971; Bicudo, 1979; Madi-Ravazzi \& Bicudo, 1992, Madi-Ravazzi et al., 1997, for examples). MadiRavazzi \& Bicudo (1992) and Madi-Ravazzi et al. (1997) demonstrated a parallel between hybrid asynapsis and postzygotic reproductive isolation in species of the Drosophila repleta group. The divergence in reproductive traits among incipient species has been well documented in this group (Markow, 1981, 1991; Bizzo, 1983; Madi-Ravazzi \& Bicudo, 1992; Marin et al., 1993; Madi-Ravazzi et al., 1997; Machado et al., 2002; Markow et al., 2002; Pitnick et al., 2003).

The Drosophila repleta species group (Diptera, Drosophilidae) occurs in different habitats, although one notable characteristic of this group is the capacity of many species to use cactus tissues for breeding and larval development (Wasserman, 1992). This adaptation has allowed the group to occupy the deserts and arid zones of the New World (Ruiz \& Fontdevila, 1981). The Drosophila buzzatii cluster of the D. repleta group (D. mulleri subgroup) is widely distributed in different types of vegetation in South America, and the polymorphism and polytypism found in geographical populations of this cluster make it very useful for ecological adaptation and speciation studies. Pioneer studies of Brazilian populations of Drosophila buzzatii found a group composed of cryptic species characterized by different polytene chromosome fixed inversions, aedeagus morphology and geographic distribution (Sene et al., 1982; Sene et al., 1988). Further studies (such as Vilela \& Sene, 1977; Silva \& Sene, 1991; Tidon-Sklorz \& Sene, 1995a,b and 2001) allowed for the description of seven species in the Drosophila buzzatii cluster.

Drosophila buzzatii has an aedeagus morphology that differs from the other six species of the cluster and presents the $5 \mathrm{~g}$ polytene chromosome fixed inversion. Drosophila buzzatii is a native of South America, but has also become cosmopolitan with the introduction of its host cactus around the world (Wasserman, 1962). The morphological aedeagus type of Drosophila borborema, which has $2 \mathrm{e}^{8}$ polytene chromosome fixed inversion, is unlike that of D. buzzatii but very similar to those of the other species of the buzzatii cluster. Drosophila borborema is distributed in northeastern Brazil and in Grão Mongol, state of Minas Gerais (Vilela \& Sene, 1977; Tidon-Sklorz \& Sene, 1995a). Drosophila koepferae, which occurs on the slopes of the Andes from Argentina to Comarapa, Bolivia, on the western side of the Chaco (Fontdevila et al., 1988), has $2 \mathrm{j}^{9}$ fixed inversion and aedeagus type E. Drosophila serido occurs in northeastern Brazil, on the eastern side of the Espinhaço mountain range and along Brazil's northeastern Atlantic coast down to the state of Rio Grande do Sul, has $2 \mathrm{x}^{7}$ fixed inversion and aedeagus type A (Vilela \& Sene, 1977). Drosophila gouveai shares $2 \mathrm{e}^{8}$ fixed inversion with $D$. borborema and D. seriema and presents aedeagus type B. It is distributed in Brazil's western Caatinga region and in the center and southeast of the country (Tidon-Sklorz \& Sene, 2001). Drosophila seriema is limited to the Espinhaço mountain range (Tidon-Sklorz \& Sene, 1995b) and presents 
aedeagus type C. Drosophila antonietae shares $2 \mathrm{x}^{7}$ fix inversion with $D$. serido; it has aedeagus type $\mathrm{D}$ and occurs in southern and southeastern regions of Brazil and on the northeastern side of the Argentinean Chaco (Tidon-Sklorz \& Sene, 2001). A common ancestry for Drosophila serido, D. gouveai, D. seriema, D. antonietae and $D$. koepferae has been suggested because of the morphometric similarity of aedeagus; considering this, Ruiz et al. (2000) proposed grouping these species into a distinct subcluster, the $D$. serido subcluster.

In the study reported here, various strains derived from allopatric populations of the Drosophila buzzatii cluster species were crossed intra- and interspecifically in order to analyze their reproductive and cytogenetic relationships. The geographical strains and their hybrids were analyzed with regard to fertility, fecundity and degree of polytene chromosome synapsis to gain further insight into the reproductive isolation process of this particular cluster species of the Drosophila repleta group.

\section{MATERIAL AND METHODS}

Fig. 1 shows the geographical strains of Drosophila buzzatii cluster species utilized in this work while Table 1 shows the crosses that were carried out. A higher number of crosses were done with Drosophila seriema strains because most of them have not yet been studied regarding reproductive aspects.

To facilitate the reader's understanding of this text, we have standardized some terms. Thus, we refer to the strains only by the first letter followed by the two first numbers, except for D69R2, D69R5 and 3B (Drosophila buzzatii strains), which will be dubbed R2, R5 and 3B, respectively. The letter F indicates females and $\mathrm{M}$ indicates males in cross direction descriptions. Intrastrain crosses mean crosses between males and females of the same strain. Intraspecific crosses mean crosses between strains belonging to the same species. Interspecific crosses are crosses between strains belonging to different species. F1 crosses are F1 progenies crossed among each other. Reciprocal crosses refer to both possible directions involved in a cross, e.g., A females crossed with B males, and B females crossed with A males are reciprocal crosses. Intra- and interspecific crosses, and the respective F1 cross boxplot graphs, were done for all the crosses described in Table 1; however, we illustrate here only the boxplot which allows for a comparison of reciprocal intra- and interspecific crosses with their respective F1 crosses (Figs. 2-5). Not all the fecundity data of crosses were included on boxplot graphs because many F1 crosses could not be done due to sterility or low productivity of some interspecific crosses. Moreover, some interspecific F1 crosses were found to be sterile (Table 2).

Virgin males and females seven to nine days old were used in all mass crossing experiments. Four crosses (1 to 4, Table 2) were done concomitantly, with 20 couples each, for all the experiments analyzed in this study. Two transfers to fresh culture medium were done at a one-week interval; the parental flies were discarded one week after the second transfer. Thus, three different age groups for each mass cross were obtained and named $1^{\text {st }}$, $2^{\text {nd }}$ and $3^{\text {rd }}$ oviposition periods. The mean age of the flies in these periods were 11,18 and 25 days old, respectively. The sex and number of individuals emerging from the crosses were computed twice a week for two weeks, making a total of four counts for each oviposition period. Fertility was also compared along the four crosses and the three oviposition periods involving the same strains. Experiments that failed to present adult progeny in any of the crosses during the various oviposition periods were considered completely sterile. On the other hand, experiments producing adult progeny in all the crosses were considered completely fertile. Experiments resulting in a few sterile crosses were regarded as partially sterile.

Fertility and fecundity were analyzed in 69 mass crosses (15 intrastrain crosses, 24 intraspecific and 30 interspecific crosses). Fertility was evaluated as larval presence or absence and fecundity or productivity as the average and total number of descendants produced in each oviposition period. The fertility and fecundity of F1 hybrids were also studied in 39 mass crosses, as described for parental crosses; however, a single transfer to fresh culture medium was done. All the flies were kept at $20{ }^{\circ} \mathrm{C} \pm 1{ }^{\circ} \mathrm{C}$.

Polytene chromosomes extracted from the salivary gland of $3^{\text {rd }}$ instar larvae were cytogenetically analyzed through slides prepared by squashing and staining with $2 \%$ lacto-acetic 


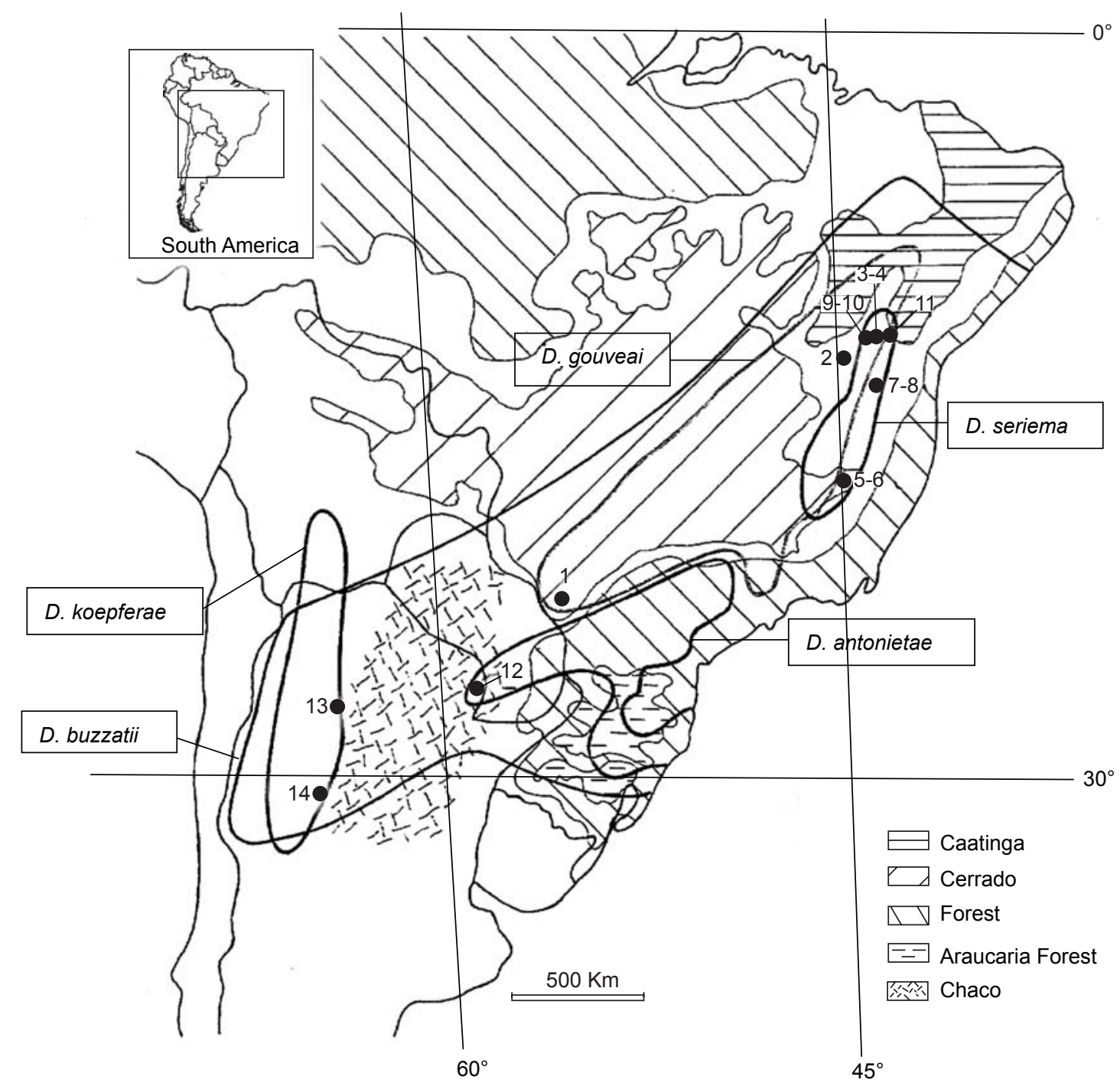

Fig. 1 - Map of the vegetation showing the distribution of species and locations of the analyzed strains (adapted from Monteiro, 1997). 1) A55F11* (Bela Vista/MS); 2) B50Q3* (Ibotirama/BA) are Drosophila gouveai strains; 3) D69R2 and 4) D69R5 (BA) are D. buzzatii strains; 5) A95F3* and 6) D40F1 (Serra do Cipó/MG), 7) D62C4BM and 8) D63M (Mucugê/ BA), 9) D71C1BM and 10) D72M (Morro do Chapéu/BA) and 11) D73C5BM (Cachoeira do Ferro Doido/BA) are D. seriema strains; 12) B31D1* (Puerto Tirol/Argentina) is D. antonietae strain; 13) B20D2* (Tapia-Tucuman/Argentina) and 14) B25D7* (Famatina-La Rioja/Argentina) are D. koepferae strains. In this study, we also analyzed 3B* strain from BA not shown on this map. Strains ending with M derive from mass cultures; the others are isofemales.

* indicates strains kept in the laboratory since 1982, and the others since 1990. Prof. Dr. Fábio de Melo Sene and collaborators collected all the strains.

orcein. Our main interest in these analyses was to observe the degree of synapsis and occurrence of heterezygote inversions in hybrid polytene chromosomes. We analyzed about 450 slides
(15 nuclei/slide) and photographed some nuclei with a Zeiss II photomicroscope.

Data were analyzed by MINITAB Release, version 10.1 for Microsoft Windows, using 
TABLE 1

Cross experiments; $\mathbf{F}=$ female; $M=$ male; $\mathrm{S}=$ intrastrain crosses; $\mathrm{A}=$ intraspecific crosses; $\mathrm{E}=$ interspecific crosses; $\mathrm{CS}=$ completely sterile interspecific crosses; $\mathrm{GOU}=$ Drosophila gouveai $; \mathrm{SER}=$ D. seriema $;$ $\mathrm{ANT}=$ D. antonietae $; \mathrm{KOE}=$ D. koepferae; and $\mathrm{BUZ}=$ D. buzzatii.

\begin{tabular}{|c|c|c|c|c|c|c|c|c|c|c|c|c|c|c|c|c|c|}
\hline & \multicolumn{15}{|c|}{ M } \\
\hline & & & \multicolumn{2}{|c|}{ GOU } & \multicolumn{7}{|c|}{ SER } & \multirow{2}{*}{\begin{tabular}{|c|} 
ANT \\
B31 \\
\end{tabular}} & \multicolumn{2}{|c|}{ KOE } & \multicolumn{3}{|c|}{ BUZ } \\
\hline & & & A55 & B50 & A95 & D40 & D62 & D63 & D71 & D72 & D73 & & B20 & B25 & 3B & R2 & R5 \\
\hline \multirow{15}{*}{$\mathbf{F}$} & \multirow[b]{2}{*}{ GOU } & A55 & $\mathrm{S}$ & - & - & - & - & E & E & - & - & - & - & - & - & $\mathrm{E}$ & $\mathrm{E}$ \\
\hline & & B50 & - & $S$ & - & - & - & - & - & - & - & - & - & $\mathrm{E}$ & - & $\mathrm{E}^{\mathrm{CS}}$ & - \\
\hline & \multirow{7}{*}{ SER } & A95 & - & - & $S$ & $\mathrm{~A}$ & - & $\mathrm{A}$ & $\mathrm{A}$ & $\mathrm{A}$ & $\mathrm{A}$ & - & - & $\mathrm{E}$ & - & $\mathrm{E}^{\mathrm{CS}}$ & - \\
\hline & & D40 & - & - & A & $S$ & A & A & A & - & A & - & - & - & - & - & - \\
\hline & & D62 & - & - & - & A & $S$ & - & - & - & - & - & - & - & - & $\mathrm{E}^{\mathrm{CS}}$ & - \\
\hline & & D63 & $\mathrm{E}$ & - & A & A & - & $S$ & - & A & - & - & - & - & - & $\mathrm{E}$ & - \\
\hline & & D71 & $\mathrm{E}$ & - & A & A & - & - & $S$ & - & - & - & - & - & - & $\mathrm{E}^{\mathrm{CS}}$ & - \\
\hline & & D72 & - & - & A & - & - & A & - & $S$ & A & - & - & - & - & $\mathrm{E}^{\mathrm{CS}}$ & - \\
\hline & & D73 & - & - & A & A & - & - & - & A & $\mathrm{S}$ & - & - & - & - & $\mathrm{E}^{\mathrm{CS}}$ & - \\
\hline & ANT & B31 & - & - & - & - & - & - & - & - & - & $S$ & - & - & - & - & $\mathrm{E}$ \\
\hline & \multirow[t]{2}{*}{ KOE } & B20 & - & - & - & - & - & - & - & - & - & - & $S$ & - & - & - & $\mathrm{E}^{\mathrm{CS}}$ \\
\hline & & B25 & - & $\mathrm{E}$ & $\mathrm{E}$ & - & - & - & - & - & - & - & - & $S$ & - & - & - \\
\hline & \multirow{3}{*}{ BUZ } & $3 B$ & - & - & - & - & - & - & - & - & - & - & - & - & $\mathrm{S}$ & - & A \\
\hline & & $\mathbf{R} 2$ & $E$ & $E$ & $\mathrm{E}^{\mathrm{CS}}$ & - & $\mathrm{E}^{\mathrm{CS}}$ & $\mathrm{E}$ & $\mathrm{E}^{\mathrm{CS}}$ & $\mathrm{E}^{\mathrm{CS}}$ & $\mathrm{E}^{\mathrm{CS}}$ & - & - & - & - & $S$ & - \\
\hline & & R5 & $\mathrm{E}$ & - & - & - & - & - & - & - & - & $\mathrm{E}$ & $\mathrm{E}^{\mathrm{CS}}$ & - & A & - & $\mathrm{S}$ \\
\hline
\end{tabular}

Student's $t$-test to measure the significance of the differences between male and female progenies. Productivity boxplot graphs were drawn using Statistica, version 5.0 for Microsoft Windows. The results presented here were also based on qualitative analyses of the graphs.

\section{RESULTS}

We observed no statistical differences between male and female progenies. Most of the intrastrain crosses were completely fertile, except the D72 (Drosophila seriema) and B20 (D. koepferae) strains, which yielded no progeny in the $3^{\text {rd }}$ oviposition period nor in one of the four crosses, respectively (Fig. 2 and Table 2). Considering intraspecific crosses, only one in 24 , F D63 x M A95 (Drosophila seriema strains) had two sterile crosses and was not fertile in the $2^{\text {nd }}$ oviposition period (Table 2 and Fig. 3). Therefore, among 30 interspecific crosses, $13(\approx 43 \%)$ were completely sterile (Table 1). Ten of these crosses involved Drosophila buzzatii (R2) and D. seriema strains while two were between $D$. buzzatii (R5) and D. koepferae (B20) and one was between $D$. gouveai (B50) females and D. buzzatii (R2) males. Among the remaining 17 interspecific crosses, about $35 \%$ were partially sterile. Considering only the interspecific F1 crosses, 33\% were partially sterile and $20 \%$ completely sterile (Table 2 ). We were unable to observe eggs or larvae in crosses that produced no adult progeny.

Intrastrain crosses involving B50 (Drosophila gouveai), D63 (D. seriema) and B31 (D. antonietae) showed low fecundity. D73 (Drosophila seriema) was the most productive strain, as clearly evidenced in the $1^{\text {st }}$ oviposition period (see Fig. 2a). The fecundity of R2 (Drosophila buzzatii) intrastrain crosses, which was similar in the three oviposition periods, was revealed by the low standard error (SE); this was not observed in any other strain. The greatest intraspecific variation and the highest SE values were obtained in D62 (Drosophila seriema) and B20 (D. koepferae) intrastrain crosses, presenting different reproductive patterns in both intra- and interspecific comparisons (Fig. 2). Regarding fecundity in the three oviposition periods, the first two periods were more productive for both intraand interspecific crosses than the third period. As for $\mathrm{F} 1$ crosses, the most productive period was the 

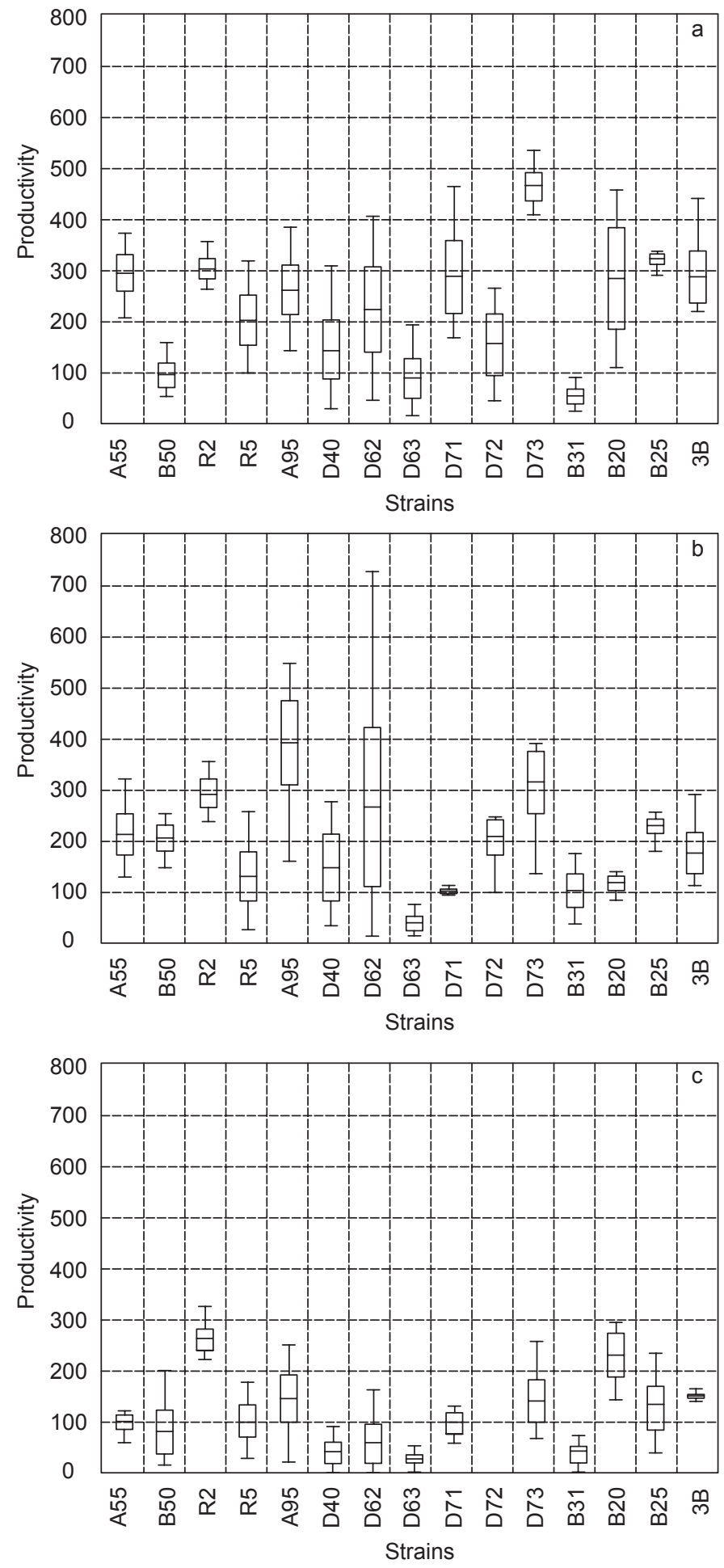

Fig. 2 - Box-plot of intracrosses productivity in three oviposition period. a) $1^{\text {st }}$ oviposition period; b) $2^{\text {nd }}$ oviposition period; and c) $3^{\text {rd }}$ oviposition period. $I=$ maximum and minimum range. $\square=$ mean \pm standard error. 


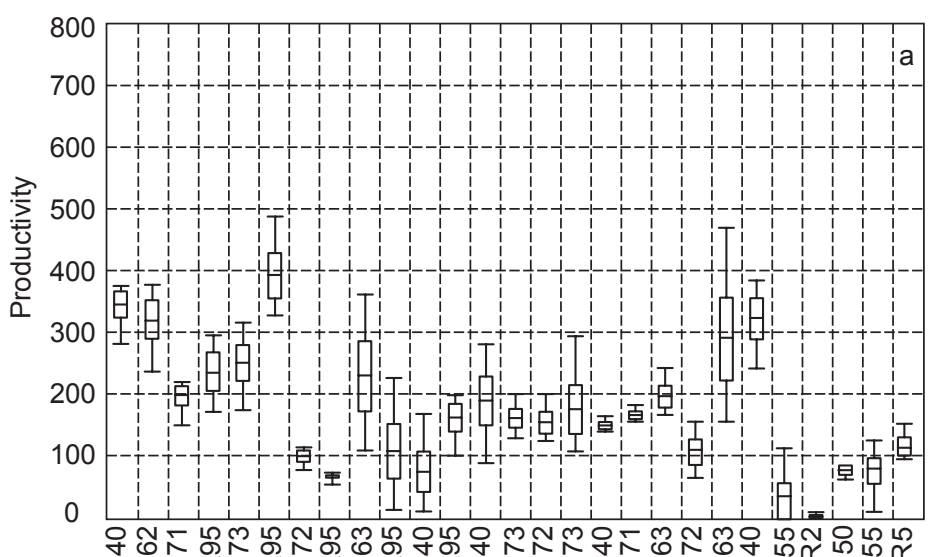

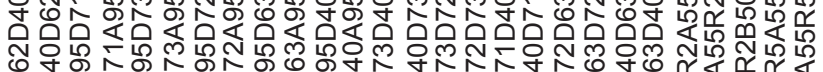

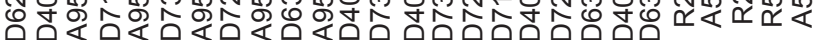

Crosses

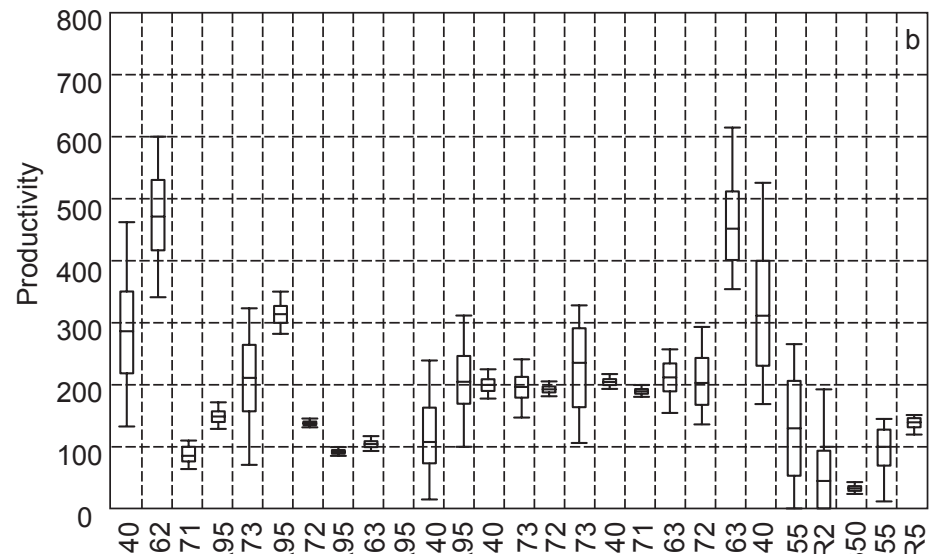

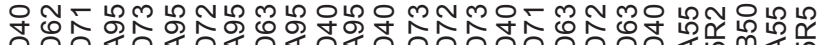

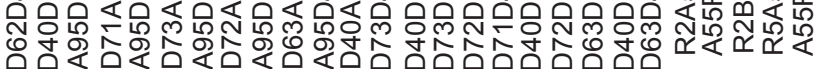
Crosses

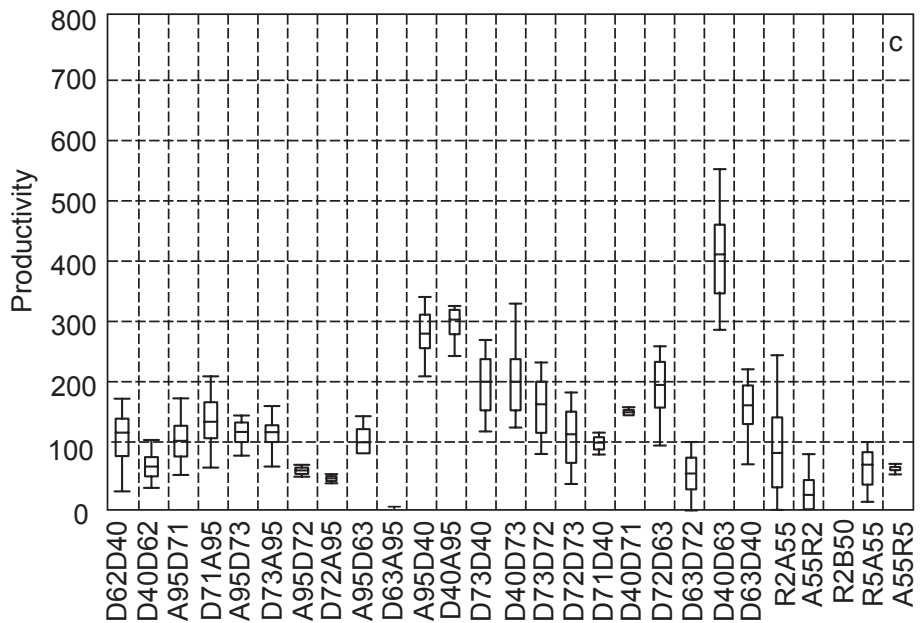

Crosses

Fig. 3 - Box-plot of reciprocal intra- and interspecifics crosses productivity in three oviposition period. The cross direction is always females $X$ males. a) $1^{\text {st }}$ oviposition period; b) $2^{\text {nd }}$ oviposition period; and c) $3^{\text {rd }}$ oviposition period. $I=$ maximum and minimum range. $\square=$ mean \pm standard error. 

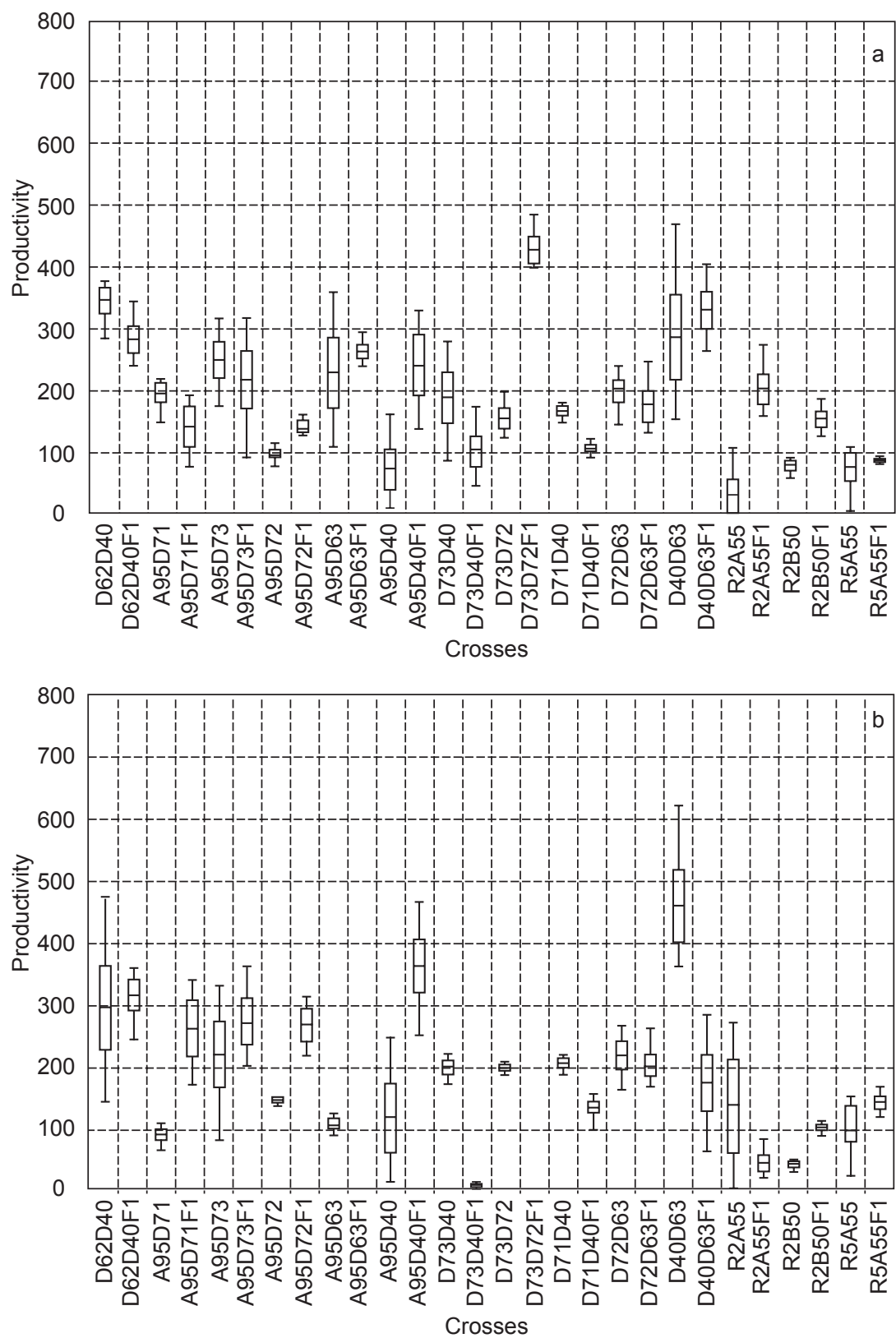

Fig. 4 - Box-plot of intra- and interspecifics crosses and theirs respective F1 crosses productivity in three oviposition period. The cross direction is always females $\mathrm{X}$ males. Crosses ended with F1 are intra- and interspecific F1 crosses. a) $1^{\text {st }}$ oviposition period; and b) $2^{\text {nd }}$ oviposition period. $I=$ maximum and minimum range. $\square=$ mean \pm standard error.

first period in the interspecific F1 crosses, and the second period in the intraspecific F1 crosses.

A comparison of the fecundity of Drosophila seriema intraspecific crosses with the respective intrastrain crosses revealed a high percentage
(40.91\%) of intraspecific crosses with productivity very similar to intrastrain crosses. Similarly, the majority of intraspecific F1 crosses presented productivity close to their respective parental intraspecific crosses (Fig. 4 and 5). In a comparison 

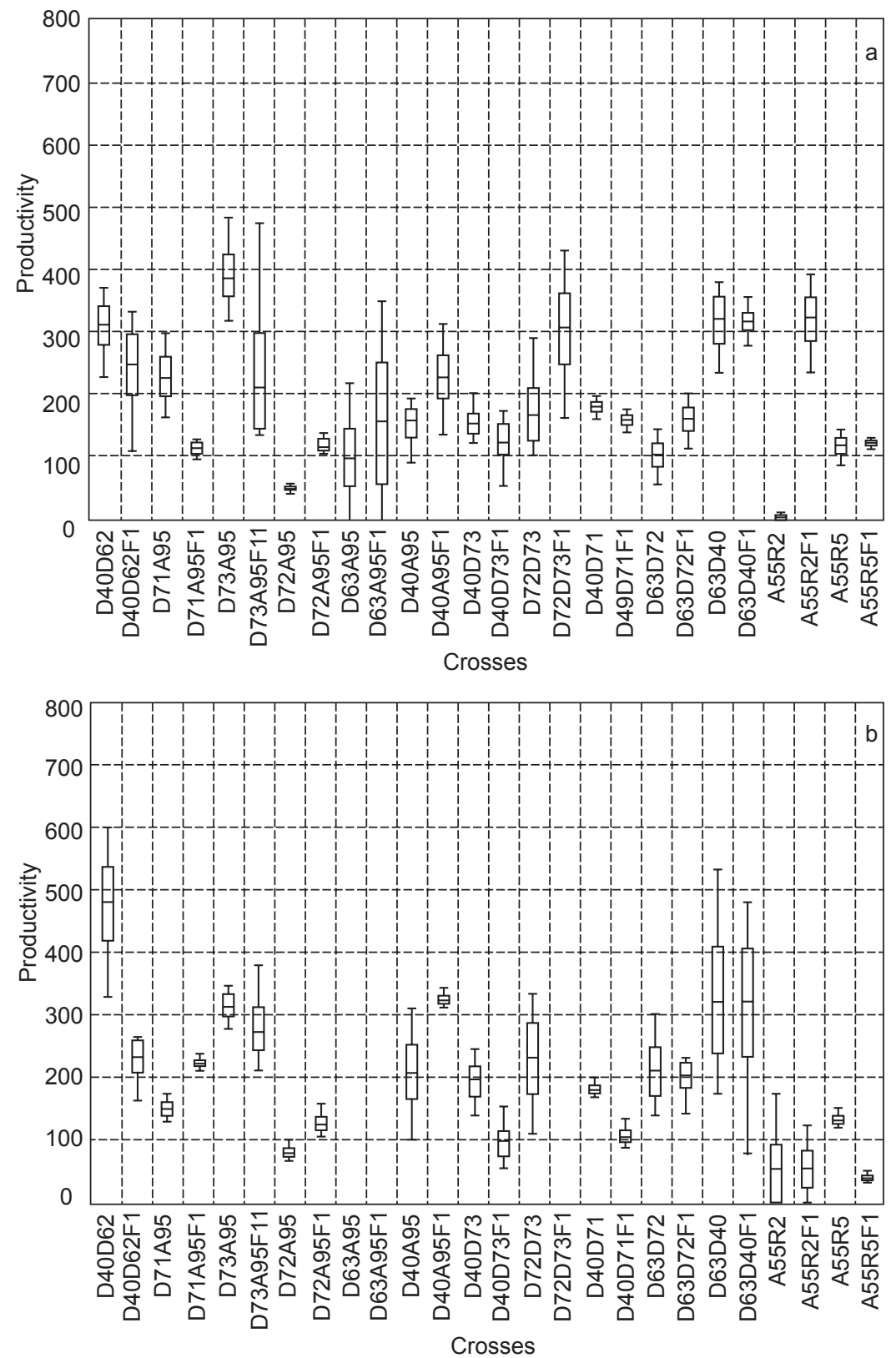

Fig. 5 - Box-plot of intra- and interspecifics crosses and theirs respective F1 crosses productivity in three oviposition period. The cross direction is always females $\mathrm{x}$ males. Crosses ended with $\mathrm{F} 1$ are intra- and interspecific $\mathrm{F} 1$ crosses. a) $1^{\text {st }}$ oviposition period; and b) $2^{\text {nd }}$ oviposition period. $I=$ maximum and minimum range. $\square=$ mean \pm standard error.

of the fecundity of Drosophila seriema reciprocal crosses, we found that the majority (63.64\%) showed a similar productivity, indicating that the cross direction does not interfere with the number of progeny (Fig. 3).
Comparing the productivity of interspecific crosses with the respective parental intrastrain crosses, we found that less than $15 \%$ of intraspecific crosses were more productive than intrastrain crosses. Similar fecundity values were 
TABLE 2

Sterile degree of crosses along the three ovipositon periods. $\mathrm{SD}=$ sterility degree; $\mathrm{PS}=$ partially sterile crosses;

CS = completely sterile crosses; $\mathbf{S}$ = intrastrains crosses; AF1 = intraspecific F1 crosses; $\mathbf{E}$ = interspecific crosses;

EF1 = interspecific F1 crosses; $F=$ female and $\mathrm{M}=$ male; $(\nabla)=$ Drosophila buzzatii; $(\square)=$ D. gouveai; $\left({ }^{\circ}\right)=$ D. seriema; $(\Delta)=$ D. antonietae $;$ and $(\bullet)=$ D. koepferae.

\begin{tabular}{|c|c|c|c|c|c|c|}
\hline \multicolumn{7}{|c|}{ Crosses } \\
\hline SD & $\mathbf{F}$ & M & 1 & 2 & 3 & 4 \\
\hline \multirow{13}{*}{ PS } & B20 (•) & B20 (•) & - & $\mathrm{S}$ & - & - \\
\hline & D63 (०) & A95 (०) & - & - & AF1 & $\mathrm{AF} 1$ \\
\hline & A55 ( $\square)$ & $\mathrm{R} 2(\nabla)$ & E & E & - & - \\
\hline & $\mathrm{R} 2(\nabla)$ & A55 ( $\square)$ & - & - & E & E \\
\hline & D63 $\left(^{\circ}\right)$ & $\mathrm{R} 2(\nabla)$ & - & E & E & E \\
\hline & $\mathrm{R} 2(\nabla)$ & D63 ( $\left.{ }^{\circ}\right)$ & - & - & E & - \\
\hline & R5 $(\nabla)$ & B31 $(\Delta)$ & - & - & $\mathrm{E}$ & E \\
\hline & B31 $(\Delta)$ & R5 ( $\nabla)$ & - & - & - & E \\
\hline & B25 (•) & A95 (०) & EF1 & - & EF1 & EF1 \\
\hline & D63 $\left(^{\circ}\right)$ & A55 ( $\square)$ & - & - & - & $\mathrm{EF} 1$ \\
\hline & A55 ( $\square)$ & D63 $\left(^{\circ}\right)$ & $\mathrm{EF} 1$ & - & - & - \\
\hline & D71 ( $\left.{ }^{\circ}\right)$ & A55 ( $\square)$ & - & - & EF1 & - \\
\hline & B50 ( $\square)$ & B25 (•) & - & EF1 & EF1 & EF1 \\
\hline \multirow{3}{*}{ CS } & A95 (०) & B25 (•) & EF1 & EF1 & EF1 & EF1 \\
\hline & B25 (•) & B50 ( $\square)$ & EF1 & EF1 & EF1 & EF1 \\
\hline & A55 ( $\square)$ & D71 $\left(^{\circ}\right)$ & EF1 & $\mathrm{EF} 1$ & EF1 & EF1 \\
\hline
\end{tabular}

found between: - reciprocal interspecific crosses; interspecific crosses and their respective intrastrain crosses; and - interspecific F1 crosses and their respective parental interspecific crosses.

The productivity of intrastrain crosses declined more markedly along the different oviposition periods than did the intra- and interspecific crosses (Fig. 2 and 3). Drosophila seriema intraspecific experiments F A95 x M D71 and F D63 x M D40 showed the highest range of oviposition periods over the four crosses. The first cross, F A95 x M D71, presented the highest SE values in the $1^{\text {st }}$ oviposition period while, in the $F$ D63 $x$ M D40 crosses, the $2^{\text {nd }}$ oviposition period was more heterogeneous (Fig. 3). The lowest fecundity among oviposition periods occurred in the Drosophila seriema intraspecific crosses F D72x M A95, and in the interspecific crosses F R2 (D. buzzatii) x M B50 (D. gouveai) and F A55 (D. gouveai) x M R2 (Fig. 3).

The degree of polytene chromosome synapsis in the progeny of intra- and interspecific crosses did not differ from that of intrastrain crosses, except for the proximal region of the $\mathrm{X}$ chromosomes and the microchromosomes (VI). These chromosomal regions showed a high degree of asynapsis in most of the analyzed cells (Fig. 6). A low rate of asynapsis was observed in the hybrid chromosomes of some intra- and interspecific crosses, e.g., in intermediate regions of the II and IV chromosomes and in the proximal region of II and V chromosomes of hybrids of Drosophila seriema strains (see Fig. 7).

We were unable to find heterozygote polymorphic inversions in hybrid polytene chromosomes, possibly due to the significant number of sterile interspecific crosses, which have a higher probability of producing inversions loops. The fertile interspecific crosses presented low fecundity, making it hard to find $3^{\text {rd }}$ instar larvae to prepare slides, even when the interspecific crosses were repeated specifically to prepare polytene chromosomes slides. No heterozygote inversions were found in the few polytene chromosome slides obtained from interspecific crosses. 

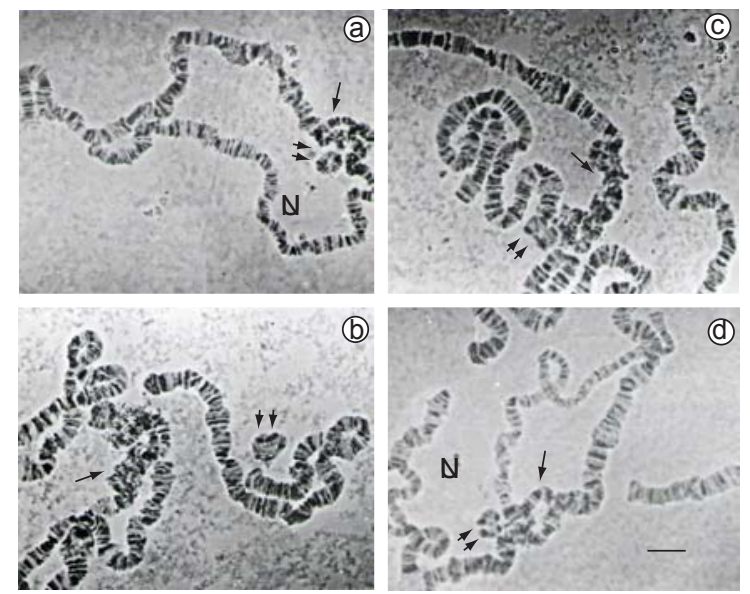

Fig. 6 - Synapsis in hybrids between F A95 x M D72 (Drosophila seriema strains). Double arrows show slightly despaired in $\mathrm{a}$ and $\mathrm{b}$ and completely despaired microchromosomes in $\mathrm{c}$ and d. Single arrows show heterochromatic aspect of the third proximal portion of chromosome X. In d, the same region is highly despaired. $(\mathrm{X} 4,270)$. Scale $=2 \mu \mathrm{m}$.
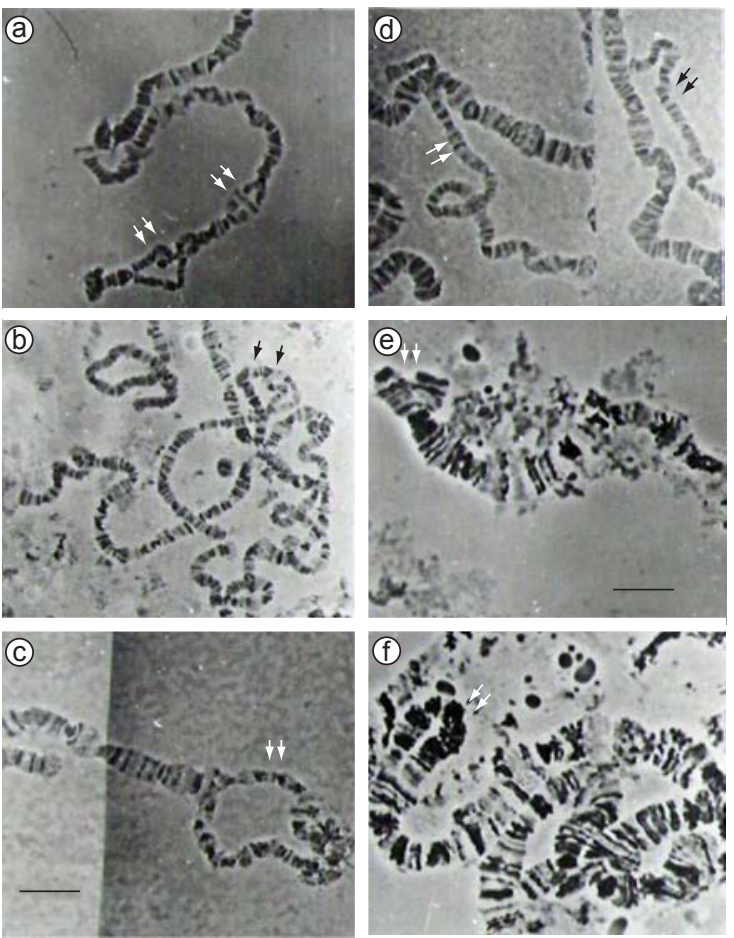

Fig. 7 - Variables degrees of asynapsis observed in intrastrains crosses and intraspecific crosses. a) Chromosome II intermediate regions of D63; b) Chromosome IV intermediate region of F D73 x M D40 hybrid; c) Chromosome X proximal region of F D72 x M A95 female hybrid; d) Chromosome V of F D72 x M A95 female hybrid; e) Chromosome V proximal region of F D73 x M D40 male hybrid; and f) Chromosome II proximal region of F D73 x M D40 male hybrid. Arrows indicate chromosomes despaired regions. a to $\mathrm{d} X 2,760$, scale in $\mathrm{c}=3 \mu \mathrm{m}$ refers to Figs. a to d; e and f X6,900, scale in e $=1.5 \mu \mathrm{m}$ refers to Figs. e and $\mathrm{f}$ ). 


\section{DISCUSSION}

Before discussing our findings, it should be noted that experimental conditions in the laboratory differ considerably from those occurring in nature; indeed, they may not even occur in nature at all. Therefore, the findings of this paper do not necessarily imply that hybridism occurs in nature. Nevertheless, our results suggest the presence or absence and the degree of genetic affinity among Drosophila buzzatii cluster species.

The high fertility observed in intrastrain crosses was expected due to the methodology of mass crosses employed here, which increases the probability of females being receptive to male courtship. Even so, one intrastrain experiment (B20, Drosophila koepferae) presented a sterile cross (Table 2), and another (D72, Drosophila seriema) had a sterile oviposition period (Fig. 2). The differences in fecundity among distinct geographical populations possibly reflect differences accumulated as a result of a long period of isolation or a bottleneck or genetic drift effect.

More than $50 \%$ of the interspecific crosses were fertile, confirming the close relation of the studied strains. Some variations in fertility and fecundity among species had already been detected earlier in the Drosophila buzzatii cluster (Bizzo, 1983; Moraes, 1992; Marin et al., 1993; MadiRavazzi et al., 1997). In addition, isolation barriers have been broken in laboratory experiments on other Drosophila species groups (Singh \& Chartterjee, 1987; Carracedo et al., 1998).

The greatest number of sterility cases and two cases of low fecundity in interspecific crosses were attained among Drosophila buzzatii with D. seriema and D. gouveai strains. Machado et al. (2002) detected premating isolation in these cases of interspecific cross sterility, probably resulting from the females' nonacceptance of male courtship. These findings reinforce previous observations that Drosophila buzzatii is, at some level, genetically isolated in the laboratory conditions from D. borborema, D. serido, D. gouveai, D. seriema and D. antonietae. Drosophila koepferae is capable of gene exchange with the Brazilian allopatric species in laboratory experiments (Madi-Ravazzi et al., 1997) and potentially with D. borborema (Wasserman, 1992), confirming the D. serido subcluster proposed by Ruiz et al. (2000). However,
Drosophila koepferae also seems to diverge to some degree from the other species of the $D$. serido subcluster. This conclusion is based on the fact that some interspecific F1 crosses carried out in this study, involving Drosophila koepferae with $D$. gouveai and D. seriema, were sterile, probably because of immobility of the hybrid male spermatozoa (Machado et al., 2002).

An impressive result was the hybridization that occurred between the D63 (Drosophila seriema) and R2 (D. buzzatii) strains. The same was not the case when R2 strain was crossed with any other Drosophila seriema strain, possibly as a result of the greater degree of geographic differentiation of this particular Drosophila seriema strain from Mucugê (BA). Kuhn et al. (1996) observed that strains from the same locality of D63 exhibited a basic metaphase karyotype unlike that of Drosophila seriema, with a smaller and telocentric (dot-like) $6^{\text {th }}$ chromosome.

In an evaluation of the reproductive compatibility among species of the Drosophila buzzatii cluster, Madi-Ravazzi et al. (1997) observed variable degrees of fertility, depending on the strains used, and also complete sterility when Drosophila buzzatii was crossed with D. serido subcluster species. Marin et al. (1993), also studying reproductive compatibility among species of the Drosophila buzzatii cluster, obtained hybrids in 10 out of 12 interspecific combinations and, in 5 cases, F1 females were partially fertile. Some of our results are congruent with MadiRavazzi et al. (1997) and Marin et al. (1993) regarding the reproductive differences between Drosophila buzzatii and D. serido subcluster species. However, the results of our work differed from theirs depending on the strains and cross directions done.

Madi-Ravazzi et al. (1997) observed complete sterility when Drosophila buzzatii was crossed with D. serido subcluster species. On the other hand, we found fertile intercrosses between Drosophila gouveai and D. buzzatii. The only asymmetric prezygotic isolation observed in this work was between Drosophila gouveai (B50) and D. buzzatii (R2). The cross between B50 females and R2 males was sterile, while the reciprocal cross was fertile. However, crosses between A55 (another Drosophila gouveai strain) with $\mathrm{R} 2$ and $\mathrm{R} 5$ were fertile, i.e., unlike B50, A55 females did not discriminate R2 
and R5 male courtship. Marin et al. (1993) obtained few hybrids when males of Drosophila buzzatii were crossed with species of $D$. serido subcluster and no descendants were produced when $D$. buzzatii females were tested. We found that intercrosses of both Drosophila buzzatii strains (R2 and R5) with most $D$. seriema strains and with $D$. koepferae were sterile in both cross directions.

The differences in our fertility results from those obtained by Madi-Ravazzi et al. (1997) and Marin et al. (1993) may be due to variations in the reproductive pattern intrinsic to these strains, probably enhanced by geographic isolation. Strains from allopatric populations may present differences in fertility through the accumulation of genetic differences; however, one must keep in mind the real possibility of methodology-related interferences in the reproductive relation of the crosses.

Noor et al. (2001) examined the genetic bases of hybrid sterility and species preferences in Drosophila pseudoobscura and D. persimilis females and proposed a genetic model whereby inversions may contribute to the speciation process, thereby explaining the numerous different arrangements among closely related species that co-occur geographically. It was also suggested that inversions create linkage groups that cause sterility to persist between hybridization taxa. Some polytene chromosome inversion studies in hybrids of different groups of Drosophila (see Coyne et al., 2002, as a recent example) suggested that sterility could be related with interaction between chromosome $\mathrm{X}$ of one species and the genome of another species. In this study, we were unable to find loops of polymorphic heterozygote inversions, mostly because of the high sterility and low fecundity among interspecific crosses.

With regard to the degree of synapsis, the studies of Madi-Ravazzi \& Bicudo (1992) and Madi-Ravazzi et al. (1997) showed differences in the banding pattern of polytene chromosomes 2 , 3 and the proximal region of chromosome $\mathrm{X}$, and a high degree of asynapsis in hybrids. They also showed the smaller degree of synapsis in hybrids of Drosophila koepferae and D. buzzatii, D. seriema and $D$. koepferae, and D. koepferae and D. serido. These species also exhibited the lowest degrees of reproductive compatibility. The Drosophila seriema and $D$. serido hybrids showed an intermediate degree of synapsis (only the proximal and distal ends were unpaired) and greater fertility than that found in other interspecific crosses.

Contrary to the findings of Madi-Ravazzi \& Bicudo (1992) and Madi-Ravazzi et al. (1997), our analysis of the degree of asynapsis in polytene chromosomes of intra- and interspecific hybrids showed a degree of unpairing not very different from that of intrastrain crosses, except for the high frequency of asynapsis in the proximal region of the $\mathrm{X}$ and microchromosomes of hybrids found here and by the aforementioned authors. Those differences may have been due to the distinct geographic strains used in these studies. The high frequency of asynapsis revealed in $\mathrm{X}$ and microchromosomes possibly indicates a homology and common origin for these two chromosomes. In fact, for Scaptodrosophila lebanonensis from the victoria group, which has no microchromosomes, Papaceit \& Juan (1998) suggest that a fusion $\mathrm{X}$-microchromosome is probably an ancestral trait in this group of species.

Populations of Drosophila buzzatii cluster species probably suffered, along with xerophytic vegetation, events of expansion during cold/dry periods of paleoclimatologic cycles (Bigarella et al., 1975; Ab'Saber, 1977; Vanzolini, 1981), and events of retraction during warm/wet periods. These changes probably contributed to events of population expansion, introgression and hybridism detected in some studies in this species cluster (Ruiz et al., 2000; Manfrin et al., 2001; de Brito et al., 2002). The last cold/dry period ended approximately 13,000 years ago. If the populations of Drosophila buzzatii cluster species suffered retraction since then, it has undergone about 156,000 generations of geographic isolation, considering one generation per month for these flies. Hence, sufficient time has elapsed for a certain degree of differentiation to have occurred in some populations, while others still conserve the ancestral genetic reproductive pattern. However, one must not disregard the possibility that some populations may have become reproductively differentiated from others of the same species through recurrent bottleneck and/or genetic drift effects during and after the retraction of populations caused by paleoclimatologic cycles.

The diagnostic characteristic among Drosophila buzzatii cluster species is its aedeagus 
morphology as long as some species share fixed inversions in the polytene chromosome, despite their specific polymorphism inversions. Aedeagus morphology is an adequate character to define groups of sibling species. Kawano (2004) demonstrated, in beetles, that animal genitalia often show distinct developmental and evolutionary relationships with other parts of the body. Therefore, the intraspecific divergence of some strains as well as other findings, such as the reproductive compatibility and chromosome pairing obtained in this and other studies, indicates that several markers are important and must be considered for a good understanding of the complexity of the speciation process.

Acknowledgments - We are indebted to Dr. Fábio de Melo Sene for providing the strains used here, to Dr. Adriana B. Santos for her help with the statistical analyses, to Dr. Paul Dean for his revision of the language and critical review, to Dr. Rogério P. Mateus for his critical review of this manuscript, to $\mathrm{CNPq}$ for a fellowship granted to L. P. B. Machado, and to FAPESP and CAPES for their financial support.

\section{REFERENCES}

AB'SABER, A. N., 1977, Espaços ocupados pela expansão dos climas secos da América do Sul, por ocasião dos períodos glaciais quaternários. Paleoclimas, 3: 1-19.

BICUDO, H. E. M. C., 1979, Estudo citogenético de espécies de Drosophila do complexo mulleri (Grupo repleta), com ênfase à regulação da atividade organizadora nucleolar. 202p. Tese (Livre Docência), Instituto de Biociências, Letras e Ciências Exatas da Universidade Estadual Paulista, IBILCE/UNESP, São José do Rio Preto.

BIGARELLA, J. J., ANDRADE-LIMA, D. \& RIEHS, P. J., 1975, Considerações a respeito das mudanças paleoclimáticas na distribuição de algumas espécies vegetais e animais no Brasil. An. Acad. Brasil. Ciênc., 41: 411-464.

BIZZO, N. M. V., 1983, Estudos sobre a biologia e isolamento reprodutivo em Drosophila serido, $71 \mathrm{p}$. Dissertação (Mestrado), Instituto de Biociências da Universidade de São Paulo, IB/USP, São Paulo.

CARRACEDO, M. C., ASENJO, A. \& CASANES, P., 1998, Inheritance mode of Drosophila simulans female mating propensity with D. melanogaster males. J. Hered., 89: 101-104.

CORDEIRO, A. R., 1968, Chromosomal pairing variability of interespecific hybrids of Drosophila willistoni cryptic group. Proc. XII Congr. Genet., 191p.

COYNE, J. A., KIM, S. Y., CHANG, A. S., LACHAISE, D. \& ELWYN, S., 2002, Sexual isolation between two sibling species with overlapping ranges: Drosophila santomea and Drosophila yakuba. Evolution, 56: 2424-2434.

DE BRITO, R. O. A., MANFRIN, M. H. \& SENE, F. M., 2002, Nested cladistic analysis of Brazilian populations of Drosophila serido. Mol. Phylogenet. Evol., 22: 131-143.
DOBZHANSKY, T., 1975, The X chromosome in the larvae salivary glands of hybrids Drosophila insularis x Drosophila tropicalis. Chromosoma, 8: 691-698.

EVGEN'EV, M. B., 1971, The pattern of polytene chromosome conjugation and crossing-over in interespecific hybrids of Drosophila. Theor. Appl. Genet., 41: 249-254.

FONTDEVILA, A., HASSON, E., WASSERMAN, M., SANCHEZ, A., NAVEIRA, H. \& Ruiz, A., 1988, Drosophila koepferae: a new member of the Drosophila serido (Diptera: Drosophilidae) superspecies taxon. Ann. Entomol. Soc. Am., 81: 380-385.

KAWANO, K., 2004, Developmental stability and adaptive variability of male genitalia in sexually dimorphic beetles. Am. Nat., 163: 1-15.

KUHN, G. C. S., RUIZ, A., ALVES, M. A. R. \& SENE, F. M., 1996, The metaphase and polytene chromosomes of Drosophila seriema (repleta group; mulleri subgroup). Rev. Bras. Genet., 19: 209-216.

LIJTMAER, D. A., MAHLER, B. \& TUBARO, P. L., 2003 , Hybridization and postzygotic isolation patterns in pigeons and doves. Evolution, 57: 1411-1418.

MACHADO, L. P. B., MADI-RAVAZZI, L. \& CASTRO, J. P., 2002, Evaluation of the courtship and of the hybrid male sterility among Drosophila buzzatii cluster species (Diptera, Drosophilidae). Rev. Brasil. Biol., 62: 601-608.

MADI-RAVAZZI, L. \& BICUDO, H. E. M. C., 1992, Differentiation of Drosophila serido (isofemale line A95F3) and $D$. koepferae (isofemale line $\mathrm{B} 20 \mathrm{D} 2$ ) reproductive isolation, development time and polytene chromosome banding patterns. Rev. Bras. Genet., 15: 831-851.

MADI-RAVAZZI, L., BICUDO, H. E. M. C. \& MANZATO, J. A., 1997, Reproductive compatibility and chromosome pairing in the Drosophila buzzatii complex. Cytobios, 89: 21-30.

MANFRIN, M. H., de BRITO, R. O. A. \& SENE, F. M., 2001, Systematics and evolution of the Drosophila buzzatii cluster (Diptera: Drosophilidae) using mtDNA. Ann. Entomol. Soc. Am., 94: 333-346.

MARIN, I., RUIZ, A., PLA, C. \& FONTDEVILA, A., 1993, Reproductive relationships among ten species of the Drosophila repleta group from South America and the West Indies. Evolution, 47: 1616-1624.

MARKOW, T. A., 1981, A courtship behavior and control of reproductive isolation between Drosophila mojavensis and Drosophila arizonae. Evolution, 35: 1022-1026.

MARKOW, T. A., 1991, Sexual isolation among populations of Drosophila mojavensis. Evolution, 45: 1525-1529.

MARKOW, T. A., CASTREZANA, S. \& PFEILER, E., 2002, Flies across the water: genetic differentiation and reproductive isolation in allopatric desert Drosophila. Evolution, 56: 546-552.

MONTEIRO, S. G., 1997, Morfometria multivariada de populações naturais de Drosophila serido, 112p. Tese (Doutorado), Faculdade de Medicina de Ribeirão Preto da Universidade de São Paulo, FMRP/USP, Ribeirão Preto.

MORAES, M. A. M., 1992, Isolamento sexual entre populações da superespécie Drosophila serido (Diptera, Drosophilidae), 91p. Dissertação (Mestrado), Instituto de 
Biociências da Universidade de São Paulo, IB/USP, São Paulo.

NOOR, M. A., GRAMS, K. L., BERTUCCI, L. A. \& REILAND, J., 2001, Chromosomal inversions and the reproductive isolation of specie. Proc. Natl. Acad. Sci. USA, 98: 12084-12088.

PAPACEIT, M. \& JUAN, E., 1998, Fate of dot chromosome genes in Drosophila willistoni and Scaptodrosophila lebanonensis determined by situ hybridization. Chromosome Res., 6: 49-54.

PITNICK, S., MILLER, G. T., SCHNEIDER, K. \& MARKOW, T. A., 2003, Ejaculate-female coevolution in Drosophila mojavensis. Proc. R. Soc. Lond. B. Biol. Sci., 270: $1507-1512$.

PRAKASH, S., 1972, Origin of reproductive isolation in the absence of apparent genic differentiation in a geographic isolate of Drosophila pseudoobscura. Genetics, 72: 143-155.

RUIZ, A. \& FONTDEVILA, A., 1981, Ecologia y evolution del subgrupo mulleri de Drosophila en Venezuela y Colombia. Acta Cient. Venezolana, 32: 338-345.

RUIZ, A., CANSIAN, A. M., KUHN, G. C. S., ALVES, M. A. R. \& SENE, F. M., 2000, The Drosophila serido speciation puzzle: putting new pieces together. Genetica, 108: 217-227.

SENE, F. M., PEREIRA, M. A. Q. R. \& VILELA, C. R., 1982, Evolutionary aspects of cactus breeding Drosophila species in South America. In: J. S. F. Barker \& W. T Starmer (eds.), Ecological genetics and evolution. The cactus-yeastDrosophila model system. Academic Press, Australia.

SENE, F. M., PEREIRA, M. A. Q. R. \& VILELA, C. R., 1988, Contrasting patterns of differentiation inferred from tradicional genetic markers in the process of speciation. Pacific Science, 42: 81-88.

SILVA, A. F. G. \& SENE, F. M., 1991, Morphological geographic variability in Drosophila serido (Diptera, Drosophilidae). Rev. Bras. Entomol., 35: 455-468.

SINGH, B. N. \& CHATTERJEE, S., 1987, Variation in mating propensity fertility in isofemale strains of Drosophila ananassae. Genetica, 73: 237-242.

TIDON-SKLORZ, R. \& SENE, F. M., 1995a, Fauna of Drosophila (Diptera, Drosophilidae) in the northern area of the "Cadeia do Espinhaço", States of Minas Gerais and Bahia, Brazil: Biogeographical and ecological aspects. Iheringia, Sér. Zool., 78: 85-94.

TIDON-SKLORZ, R. \& SENE, F. M., 1995b, Drosophila serie$m a$ n. sp.: New Member of the Drosophila serido (Diptera: Drosophilidae) Superspecies Taxon. Ann. Entomol. Soc. Am., 88: 139-142.

TIDON-SKLORZ, R. \& SENE, F. M., 2001, Two new species of the Drosophila serido sibling set (Diptera, Drosophilidae). Iheringia, Sér. Zool., 90: 141-146.

VANZOLINI, P. E., 1981, A quasi-historical approach to the natural history of the differentiation of reptiles in tropical geographic isolates. Pap. Avulsos Zool., 34: 189-204

VILELA, C. R. \& SENE, F. M., 1977, Two new Neotropical species of D. repleta group of the genus Drosophila (Diptera, Drosophilidae). Pap. Avulso Zool., 30: 295-299.

WASSERMAN, M., 1962, Cytological studies of the repleta group of the genus Drosophila. V. The mulleri group. Univ. Texas Publ., 6205: 85-118.

WASSERMAN, M., 1992, Cytological evolution of the Drosophila repleta species group. In: J. R. Powell \& C. B. Krimbas (eds.), Inversion polymorphism in Drosophila, CRC Press. Inc., Boca Raton, FL. 